\title{
PROPOSAL SKRIPSI \\ PENGARUH KUNJUNGAN WISATA KE SITUS BENTENG TUNDAKAN SEBAGAI SUMBER BELAJAR SISWA KELAS XI DI SMAN 1 PARINGIN
}

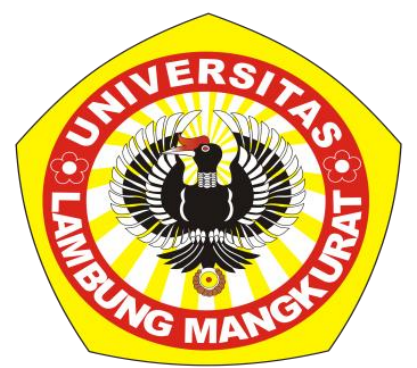

Oleh :

MUHAMMAD AKBAR SETYAWAN

NIM 1710111210016

PROGRAM STUDI PENDIDIKAN SEJARAH

FAKULTAS KEGURUAN \& ILMU PENDIDIKAN

UNIVERSITAS LAMBUNG MANGKURAT

BANJARMASIN

2019 


\section{KATA PENGANTAR}

Segala puji dan syukur senantiasa saya ucapkan atas kehadirat Allah SWT, karena dengan limpahan rahmat dan hidayah- Nya, akhirnya penulis dapat menyelesaikan Tugas Penelitian Metodologi Kuantitatif yang berjudul "PENGARUH KUNJUNGAN WISATA KE SITUS BENTENG TUNDUKAN SEBAGAI SUMBER BELAJAR SISWA KELAS XI DI SMAN 1 PARINGIN".

Penulis menyadari, karya yang penulis susun ini masih jauh dari sempurna, oleh karena itu kritik dan saran sangat penulis harapkan dari berbagai pihak. Sebagai manusia biasa, kami berusaha dengan sebaik-baiknya dan semaksimal mungkin, dan sebagai manusia biasa juga penulis tidak luput dari segala kesalahan dan kekhilafan dalam menyusun makalah ini.

Untuk menyempurnakan karya ini, penulis dengan senang hati akan menerima kritik dan saran yang sifatnya membangun dari berbagai pihak. Sehingga di kemudian hari penulis dapat menyempurnakan makalah ini dan

penulis dapat belajar dari kesalahan-kesalahan yang telah penulis lakukan. Akhirnya penulis berharap semoga makalah ini dapat bermanfaat khusunya bagi penulis dan umumnya bagi semua pihak yang berkepentingan.

Banjarmasin, 20 Juni 2020

Penulis 


\section{DAFTAR ISI}

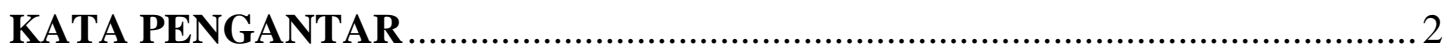

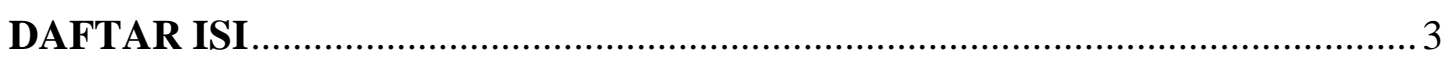

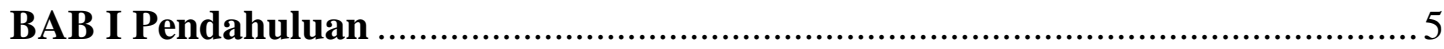

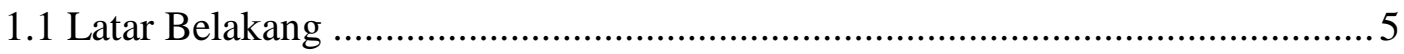

1.2 Rumusan dan Batasan Masalah .................................................................... 10

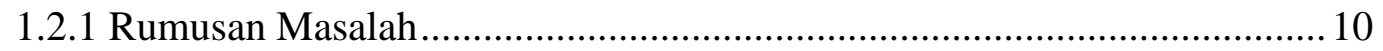

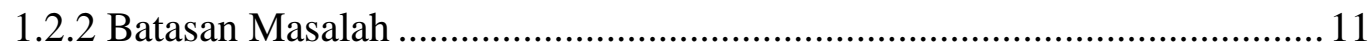

1.3 Tujuan dan Manfaat Penelitian........................................................................ 11

1.3.1 Tujuan Penelitan ................................................................................... 11

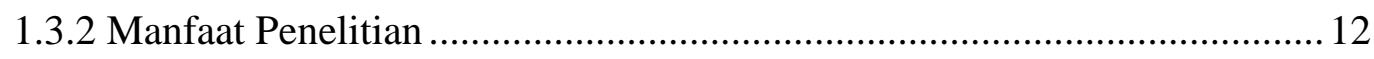

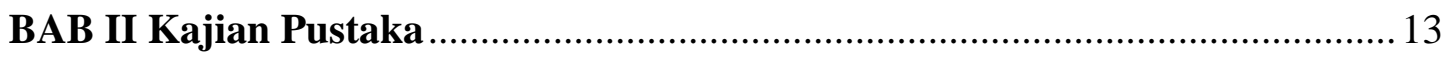

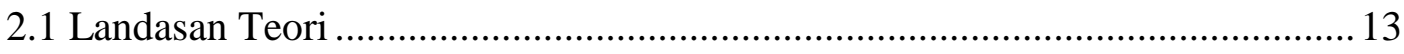

2.1.1 Pengertian Sumber Belajar ..................................................................... 13

2.1.2 Ciri-ciri Sumber Belajar....................................................................... 14

2.1.3 Klasifikasi Sumber Belajar ................................................................ 15

2.1.4 Fungsi dan Peranan Sumber Belajar.......................................................... 17

2.1.5. Kriteria Pemilihan Sumber Belajar......................................................... 18

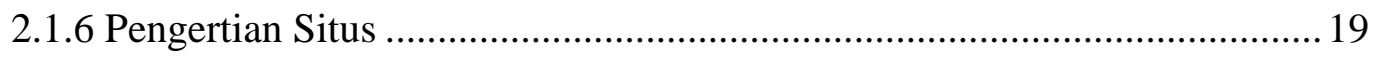

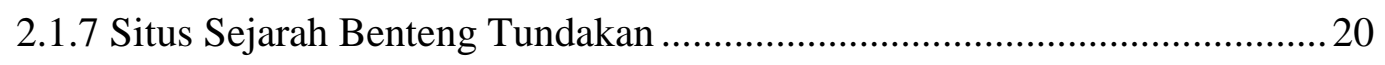

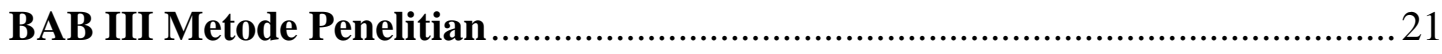

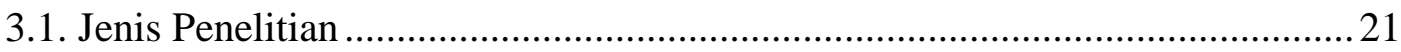

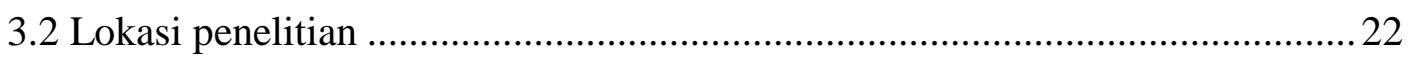

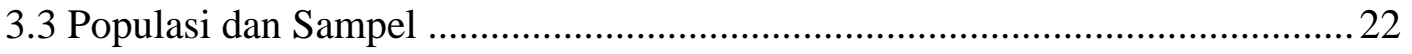

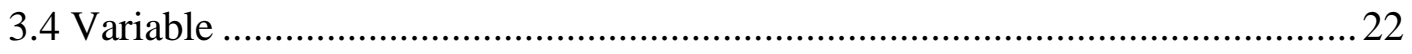

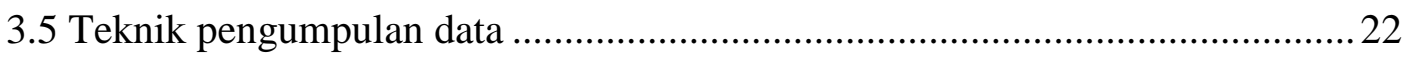

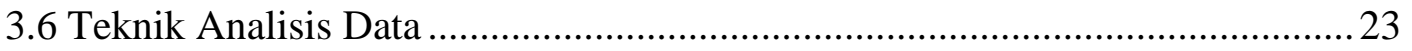




\section{BAB I}

\section{PENDAHULUAN}

\subsection{Latar Belakang}

Pendidikan merupakan suatu usaha atau kegiatan yang dijalankan dengan sengaja, teratur dan berencana dengan tujuan mengubah perilaku yang diinginka. Secara operasional, tujuan pendidikan nasional ditegaskan dalam UU RI No. 20 Tahun 2003 Bab II Pasal 3 Tentang pendidikan nasionnal yaitu bertujuan untuk mengembangkan potensi pesert didik agar menjadi manusia yang beriman dan bertaqwa kepada tuhan yang maha esa yang berakhlak mulia, sehat, berilmu, cakap, kreatif, mandiri, dan menjadi warga Negara yang demokratis dan bertanggung jawab.

Menurut Heri Susanto (Pendidikan dan kesadaran Nasionalisme 2016:307) Pendidikan dalam pengertian paling sederhana merupakan proses transfer budaya. Pendidikan dalam fakta sejarah telah membawa banyak perubahan, bukan hanya perubahan pada diri individu terdidik akan tetapi juga perubahan bangsa dan negara. Peran penting pendidikan terletak dari kemampuannya untuk membawa bangsa terjajah pada suatu kesadaran baru dalam memperjuangkan nasib bersama dan memahami kepentingan-kepentingan bersama sebagai sebuah bangsa yang berdaulat. Perkembangan pendidikan di Nusantara dapat dikatakan mengalami titik balik dengan adanya kebijakan Politik Etis. Melalui kebijakan pendidikan Politik Etis, orang-orang bumiputra harus diperkenalkan kebudayaan dan pengetahuan barat, sehingga Pemerintah Belanda banyak mendirikan sekolah-sekolahyang berorientasi barat. Secara tidak langsung, pengaruh Politik Etis terutama bidang pendidikan yaitu memberikan dampak positif bagi muncul kaum terdidik dan pergerakan di Indo- nesia. Fakta sejarah tersebut menunjukkan bahwa pendidikan berperan dalam membuka wawasan dan memperkaya pemikiran para tokoh pendiri bangsa dalam memperjuangkan nasib bangsa. Dengan demikian bahwa pendidikan mempunyai keterkaitan yang sangat besar dengan Nasionalisme Indonesia. 
Pendidikan berintikan interaksi antara pendidik dengan peserta didik dalam upaya membantu peserta didik menguasai tujuan-tujuan pendidikan. Interaksi pendidikan dapat berlangsung dalam lingkungan keluarga, sekolah ataupun masyarakat. Dalam lingkungan keluarga, interaksi terjadi antara orang tua sebagai pendidik dan anak sebagai peserta didik. Interaksi ini terjadi tanpa rencana tertulis. Orang tua sering tidak mempunyai rencana yang jelas dan rinci kemana anaknya akan diarahkan, dengan cara apa mereka dididik, dan apa isi pendidiknya. Karena sifatsifatya yang tidak formal, tidak memiliki rancangan yang kongkret dan ada kalanya juga tidak disadari, maka pendidikan dalam lingkungan keluarga tersebut pendidikan informal.

Pendidikan di Indonesia diselenggarakan secara formal, nonformal dan informal pendidikan formal meliputi pendidikan dasar yang diselenggarakan di Sekolah Dasar (SD) atau Madrasah Ibtidayah (MI) dan sekolah Menengah Pertama (SMP) atau Madrasah Tsanawiyah (MTs) dan Sekolah Menengah Atas (SMA) atau Madrasah Aliyah (MA) dan pendidikan tinggi yang diselenggarakan di Perguruan Tinggi (PT). Pendidikan nonformal diselenggarakan bagi warga masyarakat yang memerlukan layanan pendidikan yang berfungsi sebagai pengganti, penambahan, atau pelengkap pendidikan formal dalam rangka mendukung pendidikan sepanjang hayat, sedangkan pendidikan informal yang dilakukan oleh keluarga dan lingkungan berbentuk kegiatan belajar secara mandiri.

Pendidikan dalam lingkungan sekolah lebih bersifat formal. Guru sebagai tenaga pendidik disekolah telah dipersiapkan secara formal dalam lembaga pendidikan guru. Guru melaksanakan tugasnya sebagai tenaga pendidik dengan rencana dan persiapan yang matang. Merek mengajarkan dengan tujuan yang jelas, bahan- bahan yang disusun secara sistematis dan rinci, dengan cara dan alat-alat yang telah dipilih dan dirancang secara cermat. Di sekolah tenaga pendidik melakukan interaksi pendidikan secara berencana dan sadar. Dalam lingkungan sekolah telah ada kurikulum 
formal yang bersifat tertulis. Guru-guru melaksanakan tugas mendidik secara formal, karena itu pendidikan diskeolah sering disebut pendidikan formal.

Pendidikan formal memiliki rancangan pendidikan atau kurikulum tertulis yang tersusun secara sistematis, jelas dan rinci. Ini merupakan salah satu cirri dari pendidikan formal dan harus ada dalam perangkat pendidikan formal tersebut. Kurikulum merupakan syarat mutlak, hal itu berarti bahwa kurikulum merupakan bagian yang tidak terpisahkan dari pendidikan atau pengajaran. Dapat kita bayangkan bagaimana bentuk pelaksanaan suatu pendidikan atau pengajaran disekolah yang tidak memiliki kurikulum.

Kurikulum mempunyai kedudukan sentral dalam seluruh proses pendidikan. Kurikulum. Mengarahkan segala bentuk aktivitas pendidikan demi tercapainya tujuatujuan pendidikan. Kurikulum juga merupakan suatu rencana pendidikan, memberikan pedoman dan pegangan tentang jenis, lingkup, dan urutan isi, serta proses pendidikan. Disamping kedua fungsi itu, kurikulum juga merupakan suatu bidang studi, yang ditekuni oleh para ahli atau spesialis kurikulum, yang menjadi sumber konsep-konsep atau memberikan landasan-landasan teoritis bagi pengembangan kurikulum berbagai institusi pendidikan.

Sekolah Menengah Atas (SMA) dan Madrasah Aliyah (MA) atau yang sederajat merupakan salah satu jenjang pendidikan menengah pendidikann formal di Indonesia untuk kelanjutkan pendidikan dasar serta menyiapkan peserta didik (siswa) menjadi anggota masyarakat yang memiliki kemampuan lebih lanjut dalam dunia kerja atau pendidikan tinggi. Sekolah Menengah Atas (SMA) dan Madrasah Aliyah (MA) atau yang sederajat ditempuh dalam waktu 3 tahun, mulai dari kelas X sampai kelas XII. Pada tahun pertama atau kelas X peserta didik siswa sudah memilih jurusan dimana kalau di SMA ada tiga yaitu Matematika Ilmu Alam (MIA), Ilmu Ilmu Sosial (IIS) dan Ilmu Bahasa dan Budaya (IBB) sedangkan di Madrasah Aliyah sendiri juga sama denga yang di SMA namun bertambah satu yaitu Ilmu-ilmu Keagamaan (IIK) . 
Sejarah merupakan salah satu mata pelajaran yang diberikan dalam pembelajaran disekolah. Sejarah menjadi unsur yang penting bagi ilmu-ilmu sosial. Baik konsep maupun tujuan pembelajaran mata pelajaran ini untuk berbagai tingkat telah ditetapkan ulang. Sejarah diharapkan mencapai potensi penuhnya sebagai mata pelajaran pada setiap tingkat pada system pendidikan sehingga menjadi sangat penting untuk melengkapi para guru dengan konsep-konsep, prosedur, dan teknik pembelajarn yang mutakhir, yang tidak ada akan mencapai kesuksesan kecuali guru bersedia bekerja sama, bekerja keras, dan menggunakan tata cara pembelajaran yang baru.

Menurut M.Z. Arifin Anis (Sejarah, Pendidikan Sejarah, Dan Pendidikan Karakter Dialog Yang Tidak Pernah Dituntaskan 2014:485) Apabila dicermati tujuan pembelajaran sejarah di atas maka guru sejarah harus memahami filsafat konstruksionisme yang berpijak bagaimana siswa membangun pengalaman belajarnya dan proses keaktifan dalam proses pembelajaran. Proses belajar yang diinginkan oleh konstruktivisme mengharuskan, guru memposisikan dirinya sejajar dengan siswa sehingga terjalin dinamika pembelajaran di kelas.

Pembelajaran tidak hanya merupakan suatu proses interaksi antara guru dengan siswa tetapi juga interaksi antara siswa dengan siswa. Keaktifan siswa dituntut dalam kegiatan pembelajaran guna menunjang keberhasilan proses belajar m engajar dan memperoleh manfaat dari kegiatan tersebut. Hal ini sejalan dengan pernyataan yang disampaikan Usman da Setiawan (2001), bahwa berhasil tidaknya pencapaian tujuan pedidikan banyak bergantung kepada bagaiman proses belajar yang dialami peserta didik.

Menurut Herry Porda Nugroho Putro (Museum Sebagai Wahana Pendidikan Karakter Di Kalimantan Selatan 2014: 408) Kekayaan budaya sebagai hasil cipta, rasa, karsa di Kalimantan Selatan telah dikelola dengan baik, seperti pada setiap jenjang pendidikan yang mencoba memasukkan aspekaspek budaya dalam muatan lokal dan keunggulan lokal, media massa (cetak dan elektronik), festival tahunan budaya Banjar, 
dan lomba-lomba kesenian. Sangat disayangkan kegiatan budaya Banjar tersebut hanya berpengaruh pada saat itu saja setelah siswa mendapat nilai, waktu terbatas, dan terbatas pada siapa yang membaca.

Berkaitan dengan aktivitas siswa dalam proses pembelajaran, salah satu factor yang perlu diperhatikan adalah menyangkut masalah respon atau tanggapan siswa terhadap pembelajaran yang dilaksanakan. Bagaimana kita mengkonsep agar pembelajaran yang dilakukan mnedapat respon positif dari siswa. Untuk itu tenaga pendidik harus jeli untuk memilih teknik, media, sumber da model pembelajaran dan memanfaatkan sarana dan prasarana sebagai penunjang tercapaianya tujuan pembelajaran. Tenaga pendidik juga bisa menggunakan saran atau cagar budaya yang ada didaerah sekitar kita utuk membuat proses pembelajaran tersebut menjadi lebih menarik.

Oleh karena itu, untuk memperoleh respon positif dari para peserta didik dalam pembeljaran dan berkaitan dengan pemanfaata sarana yang menunjang pembelajaran, hendaknya tenaga pendidik menggunakan sumber sejarah seperti situs benteng yang ada disekitar sekolah. dengan penggunaan situs benteng tersebut dapat menambah menarik pembelajaran dan mempengaruhi hasil belajar siswa. Pembelajaran dengan menggunakan situs candi ini dapat digunakan sekolah-sekolah di Kabupaten Balangan untuk menjadi sumber belajar.

Benteng Tundukan adalah sebuah situs atau sisa-sisa peninggalan kepurbaklaan, yang berada di desa Tundukan Hulu Kecamatan Awayan Kabupaten Balangan Provinsi Kalimantan selatan.

Letaknya tersebut didesa Tundukan di awayan, merupakan tempat yang termasuk garis pertahanan Pengeran Antasari di Hulu Sungai (Banua Lima) dibawah Penglima Perang Tumenggung Jalil.Kini Benteng Tundakan merupakan salah satu dari tiga tempat Cagar Budaya di Kabupaten Balangan yang langsung dibawah naungan Balai Pelestarian Cagar Budaya Samarinda yang dibawahi langsung oleh direktur 
jendral kebudayaan kementerian Pendidikan Nasional Indonesia.Juru pelihara Benteng Tundakan, Muhammad Ilmi mengungkapkan, luas areal Benteng Tundakan sesuai dengan pagar keliling yang dibuat semasa Balangan masih jadi satu dengan Hulu Sungai Utara adalah sekitar lebar 200 meter dan panjang 100 meter.

Penetapan SMAN 1 Paringin sebagai lokasi penelitian anatara lain karena lokasi SMAN 1 Paringin tidak jauh dari situs sejarah Benteng Tundukan yang dapat digunakan sebagai sumber pembelajaran sejarah. Penggunaan Benteng Tundukan sebagai sumber belajar sejarah tersebut sesuai dengan inovasi pembelajarn yang diharapkan dalam Kurikulum 2013 Revisi 2017, hal ini juga mengacu pada prinsip pelaksanaan dan prinsip pengembangan kurikulum yang dibuat oleh Pemerintah

Dari uraian di atas maka permasalahan yang diungkap dalam Proposal Skripsi ini adalah : "PENGARUH KUNJUNGAN WISATA KE SITUS BENTENG TUNDUKAN SEBAGAI SUMBER BELAJAR SISWA KELAS XI DI SMAN 1 PARINGIN".

\subsection{Rumusan dan Batasan Masalah}

\subsubsection{Rumusan Masalah}

Berdasarkan pada uraian latar belakang, maka penelitian mengenai Pengaruh Situs Benteng Tundukan Sebagai Sumber Pembelajaran Sejarah Siswa Kelas XI di SMAN 1 Paringin, dirumuskan dengan pertanyaan sebagai berikut:

1. Bagaimana kegiatan belajar sejarah yang menggunakan situs sejarah Benteng Tundukan sebagai sumber belajar sejarah pada siswa kelas XI SMAN 1 Paringin ?

2. Bagaimana tingkat keberhasilan belajar siswa kelas XI di SMAN 1 Paringin dengan memanfaatkan Situs Benteng tundukan sebagai sumber belajar sejarah? 
3. Bagaimana pengaruh dari pemanfaatan situs sejarah Benteng Tundukan sebagai sumber belajar sejarah pada siswa kelas XI SMAN 1 Paringin?

\subsubsection{Batasan Masalah}

Dalam penelitian ini penulis senngaja membatasi permasalahan pada :

1. Sejauh mana penggunaan situs sejarah Benteng Tundukan sebagai sumber belajar sejarah pada siswa kelas XI SMAN 1 Paringin.

2. Sejauh mana manfaat pemakaian sumber belajar situs Benteng Tundukan dalam mata pelajaran sejarah tingkat SMA/MA pada siswa kelas XI SMAN 1 Paringin.

\subsection{Tujuan dan Manfaat Penelitian}

\subsubsection{Tujuan Penelitan}

Sesuai dengan rumusan masalah diatas, maka secara umum tujuan penelitian ini untuk mendiskripsikan pemanfaatan situs sejarah sebagai sumber belajar sejarah siswa kelas XI SMAN 1 Paringin. Tujuanya ini kemudian dijabarkan lagi menjadi tujuan khusus yang ingin dicapai dalam penelitian ini adalah :

1. Mengetahui pengaruh pemanfaatan situs Beneng Tundakan Sebagai Sumber belajar sejarah siswa kelas XI SMAN 1 Paringin.

2. Mengetahui peranan Benteng Tundakan sebagai sumber belajar sejarah kelas XI SMAN 1 Paringin

3. Menghimpu data dan mengidentifikasi peranan Benteng Tundakan sebagai sumber belajar sejarah pada siswa kelas XI SMAN 1 Paringin. 


\subsubsection{Manfaat Penelitian}

1. Untuk menambah wawasan penulis dalam hal yang berkenaan dengan masalah penelitian itu sendiri.

2. Diharapkan dengan adanya penulisan ini dapat memberikan wawasan tentang peran situs Sejarah Benteng Tundakan sebagai sumber belajar kelas XI SMAN 1 Paringin.

3. Diharapkan temuan dalam penelitian ini dapat menjadi bahan informasi bagi tenaga pendidik dan pihak-pihak terkait dalam bidang pendidikan untuk meningkatkan kualitas/prestasi belajar siswa. 


\section{BAB II}

\section{KAJIAN PUSTAKA}

\subsection{Landasan Teori}

\subsubsection{Pengertian Sumber Belajar}

Sumber belajar dalam pengertian sempit dirtikan sebagai semua sarana pengajaran yang menyajikan pesan secara edukatif baik visual saja maupun audiovisual, misalnya buku-buku dan bahan tercetak lainnya. Pengertian ini masih banyak disepakati oleh guru dewasa ini. Misalnya, dalam program pengajaran yang biasa disusun oleh para guru, kompenen sumber belajar pada umumnya akan diisi dengan buku teks atau buku wajib yang dianjurkan.

AECT (Association of Education and Communication Technology) (1977) mendefinisikan sumber belajar adalah berbagai atau semua sumber baik yang berupa data, orang dan wujud tertentu yang digunakan oleh siswa dalam belajar baik secara terpisah maupun terkombinasi sehingga mempermudah siswa dalam mencapai tujuan belajar. Sumber belajar menurut AECT dibedakan menjadi enam jenis, yaitu:

a. Pesan (massage), yaitu informasi yang ditransmisikan atau diteruskan oleh komponen lain dalam bentuk ide, ajaran, fakta, makna, nilai dan data. Contoh: isi bidang studi yang dicantumkan dalam kurikulum pendidikan formal, dan non formal maupun dalam pendidikan informal.

b. Orang (person), yaitu manusia yang berperan sebagai pencari, penyimpan, pengelolah dan penyaji pesan. Contoh: guru, dosen, tutor, siswa, pemain, pembicara, instruktur dan penatar.

c. Bahan (material), yaitu sesuatu ujud tertentu yang mengandung pesan atau ajaran untuk disajikan dengan menggunakan alat atau bahan itu sendiri tanpa alat penunjang apapun. Bahan ini sering disebut sebagai media atau software atau perangkat lunak. Contoh: buku, modul, majalah, bahan pengajaran terprogram, 
transparansi, film, video tape, pita audio (kaset audio), filmstrip, microfiche dan sebagainya.

d. Alat (Divice), yaitu suatu perangkat yang digunakan untuk menyampaikan pesan yang tersimpan dalam bahan. Alat ini disebut hardware atau perangkat keras. Contoh: proyektor slide, proyektor film, proyektor filmstrip, proyektor overhead (OHP), monitor televisi, monitor komputer, kaset, dan lain-lain.

e. Tehnik (Technique), dalam hal ini tehnik diartikan sebagai prosedur yang runtut atau acuan yang dipersiapkan untuk menggunakan bahan peralatan, orang dan lingkungan belajar secara terkombinasi dan terkoordinasi untuk menyampaikan ajaran atau materi pelajaran. Contoh: belajar mandiri, belajar jarak jauh, belajar secara kelompok, simulasi, diskusi, ceramah, problem solving, tanya jawab dan sebagainya.

f. Lingkungan (setting), yaitu situasi di sekitar proses belajar-mengajar terjadi. Latar atau lingkungan ini dibedakan menjadi dua macam yaitu lingkungan fisik dan non fisik. Lingkungan fisik seperti gedung, sekolah, perpustakaan, laboratorium, rumah, studio, ruang rapat, musium, taman dan sebagainya. Sedangkan lingkungan non fisik contohnya adalah tatanan ruang belajar, sistem ventilasi, tingkat kegaduhan lingkungan belajar, cuaca dan sebagainya.

Sumber belajar dalam pengertian luas adalah seperti pengertian yang dikemukakan oleh Edgar Dale. Dia menyatakan bahwa pengalaman itu adalah sumber belajar. Sumber belajar dalam pengertian ini menjadi sangat luas maknanya, seluas hidup itu sendiri, karena segala sesuatu yang dialami peserta didik dianggap sebagai sumber belajar, sepanjang hal itu memberi pengalaman yang menyebabkan mereka belajar.

\subsubsection{Ciri-ciri Sumber Belajar}

Sumber belajar mempunyai empat ciri pokok, yaitu: 
a. Sumber belajar mempunyai daya atau kekuatan yang dapat memberikan sesuatu yang kita perlukan dalam proses pengajaran. Jadi, walaupun sesuatu daya, tetapi tidak memberikan sesuatu yang kita inginkan, sesuai dengan tujuan pengajaran, maka sesuatu daya tersebut tidak dapat disebut sebagai sumber belajar.

b. Sumber belajar dapat merubah tingkah laku yang lebih sempurna, sesuai dengan tujuan. Apabila dengan sumber belajar malah membuat seseorang berbuat dan bersifat negatif maka sumber belajar tersebut tidak dapat disebut sebagai sumber belajar. Misalnya setelah seseorang menonton film, ada isi/pesan fim tersebut mempunyai dampak negatif terhadap dirinya maka film tersebut bukanlah sumber belajar.

c. Sumber belajar dapat dipergunakan secara sendiri-sendiri (terpisah), tetapi tidak dapat digunakan secara kombinasi (gabungan). Misalnya sumber belajar material dapat dikombinasi denga devices dan strategi (motode). Sumber belajar modul dapat berdiri sendiri. d. Sumber belajar secara bentuk dapat dibedakan menjadi dua, yaitu sumber belajar yang dirancang (by designed), dan sumber belajar yang tinggal pakai (by utilization). Sumber belajar yang dirancang adalah sesuatu yang memang dari semula dirancang untuk keperluan belajar. Sedangkan sumber belajar yang tinggal pakai sesuatu yang pada mulanya tidak dimaksudkan untuk kepentingan belajar, tetapi kemudian dimanfaatkan untuk kepentingan belajar. Ciri utama sumber belajar yang tinggal pakai adalah: tidak terorganisir dalam bentuk isi yang sistematis, tidak memiliki tujuan pembelajarn yang ekspilit, hanya dipergunakan menurut tujuan tertentu dan bersifat insidental, dan dapat dipergunakan untuk berbagai tujuan pembelajaran yang relevan dengan sumber belajar tersebut.

\subsubsection{Klasifikasi Sumber Belajar}

Secara lebih jelas berikut klasifikasi jenis-jenis sumber belajar.

Tabel 1 
Klasifikasi sumber belajar

\begin{tabular}{|c|c|c|c|}
\hline $\begin{array}{c}\text { Jenis } \\
\text { Sumber } \\
\text { Belajar }\end{array}$ & Pengertian & Pengertian & Dimanfaatkan \\
\hline $\begin{array}{l}\text { Pesan } \\
\text { (Masssage) }\end{array}$ & $\begin{array}{l}\text { Informasi yang } \\
\text { harus } \\
\text { disalurkan oleh } \\
\text { komponen lain } \\
\text { berbentuk ide, fakta, } \\
\text { pengertian data. }\end{array}$ & $\begin{array}{l}\text { Bahan-bahan } \\
\text { pelajaran }\end{array}$ & $\begin{array}{c}\text { Cerita rakyat, } \\
\text { dongeng, } \\
\text { nasihat. }\end{array}$ \\
\hline $\begin{array}{l}\text { Manusia } \\
\text { (People) }\end{array}$ & $\begin{array}{l}\text { Orang yang } \\
\text { menyimpan } \\
\text { informasi atau } \\
\text { menyalurkan } \\
\text { informasi. Tidak } \\
\text { termasuk } \\
\text { yang menjalankan } \\
\text { fungsi } \\
\text { pengembangan dan } \\
\text { pengelolaan sumber } \\
\text { belajar. }\end{array}$ & $\begin{array}{l}\text { Guru, aktor, } \\
\text { siswa, } \\
\text { pembicara, } \\
\text { pemain. } \\
\text { Tidak } \\
\text { termasuk } \\
\text { teknisi ilmu } \\
\text { kurikulum }\end{array}$ & $\begin{array}{l}\text { Narasumber, } \\
\text { pemuka } \\
\text { masyarakat, } \\
\text { pimpinan } \\
\text { kantor, } \\
\quad \text { responden. }\end{array}$ \\
\hline $\begin{array}{l}\text { Bahan } \\
\text { (materials) }\end{array}$ & $\begin{array}{l}\text { Sesuatu, bisa disebut } \\
\text { media/software yang } \\
\text { mengandug pesan } \\
\text { untuk disajikan } \\
\text { melalui pemakaian } \\
\text { alat }\end{array}$ & $\begin{array}{l}\text { Transparansi, film, } \\
\text { slides, tape, buku, } \\
\text { gambar dan lain- } \\
\text { lain. }\end{array}$ & $\begin{array}{l}\text { Rellef, candi, arca, } \\
\text { peralatan tehnik }\end{array}$ \\
\hline $\begin{array}{l}\text { Peralatan } \\
\text { (device) }\end{array}$ & $\begin{array}{l}\text { Sesuatu, bisa disebut } \\
\text { media/ hardware } \\
\text { yang menyalurkan } \\
\text { pesan untuk } \\
\text { disajikan yang } \\
\text { ada di dalam } \\
\text { software. }\end{array}$ & $\begin{array}{l}\text { OHP, proyektor, } \\
\text { slides, film, TV, } \\
\text { kamera, papan tulis. }\end{array}$ & $\begin{array}{l}\text { Generator, mesin. } \\
\text { Alatalat, mobil. }\end{array}$ \\
\hline $\begin{array}{l}\text { Tehnik/ } \\
\text { Metode } \\
\text { (technique) }\end{array}$ & $\begin{array}{l}\text { Prosedur yang } \\
\text { disiapkan } \\
\text { dalam } \\
\text { mempergunakan } \\
\text { bahan pelajaran, }\end{array}$ & $\begin{array}{l}\text { Ceramah, } \\
\text { Diskusi, } \\
\text { sosiodrama, } \\
\text { simulasi, } \\
\text { kuliah, }\end{array}$ & $\begin{array}{l}\text { Permainan, } \\
\text { sarasehan, } \\
\text { percakapan } \\
\quad \text { biasa/ spontan }\end{array}$ \\
\hline
\end{tabular}




\begin{tabular}{|l|l|l|l|}
\hline & $\begin{array}{l}\text { peralatan, situasi, } \\
\text { dan orang untuk } \\
\text { menyampaikan } \\
\text { pesan. }\end{array}$ & $\begin{array}{l}\text { belajar } \\
\text { mandiri. }\end{array}$ & pasar, museum, took \\
\hline $\begin{array}{l}\text { Lingkungan } \\
\text { setting })\end{array}$ & $\begin{array}{l}\text { Situasi sekitar di } \\
\text { mana pesan } \\
\text { disalurkan/ } \\
\text { ditransmisikan. }\end{array}$ & $\begin{array}{l}\text { Ruangan } \\
\text { kelas, studio, } \\
\text { perpustakaan, } \\
\text { auditorium, } \\
\text { aula }\end{array}$ \\
\hline
\end{tabular}

Klasifikasi lain yang biasa dilakukan terhadap sumber belajar adalah sebagai berikut:

a. Sumber belajar tercetak. Contohnya: buku, majalah, brosur, koran, poster, denah, ensiklopedi, kamus, booklet, dan lain-lain.

b. Sumber belajar non cetak. Contohnya; film, slides, video, model, transparansi, reali, dan lain-lain.

c. Sumber belajar yang berbentuk fasilitas. Contohnya perpustakaan, ruangan belajar, carrel, studio, lapangan olah raga dan lain-lain.

d. Sumber belajar berupa kegiatan. Contohya: wawancara, kerja kelompok, observasi, simulasi, permainan dan lain-lain.

e. Sumber belajar berupa lingkungan di masyarakat. Contohnya: taman, terminal, pasar, toko, pabrik, museum dan lain-lain

\subsubsection{Fungsi dan Peranan Sumber Belajar}

Fungsi sumber belajar antara lain:

a. Meningkatkan produktifitas pendidikan dengan jalan:

1) Membantu guru untuk menggunakan waktu dengan secara lebih baik dan efektif. 
2) Meningkatkan laju kelancaran belajar.

3) Mengurangi beban guru dalam penyajian informasi, sehingga lebih banyak kesempatan dalam pembinaan dan pengembangan gairah belajar.

b. Memberikan kemungkinan pendidikan yang sifatnya lebih individual dengan jalan:

1) Mengurangi fungsi kontrol guru yang sifatnya yang kaku dan tradisional.

2) Memberikan kesempatan pada siswa untuk berkembang sesuai dengan kemampuannya.

c. Memberikan dasar-dasar pengajaran yang lebih ilmiah, dengan jalan:

1) Merencanakan program pendidikan secara lebih sistematis.

2) Mengembangkan bahan pengajaran melalui upaya penelitian terlebih dahulu.

d. Meningkatkan pemantapan pengajaran dengan jalan:

1) Meningkatkan kemampuan manusia dengan berbagai media komunikasi.

2) Menyajikan informasi maupun data secara lebih mudah, jelas dan kongkrit.

\subsubsection{Kriteria Pemilihan Sumber Belajar}

Kriteria pemilihan sumber belajar yang perlu diperhatikan adalah sebagai berikut:

a. Tujuan yang ingin dicapai, ada sejumlah tujuan yang ingin dicapai, dengan menggunakan sumber belajar dipergunakan untuk menimbulkan motivasi, untuk keperluan pengajaran, untuk keperluan penelitian 
ataukah untuk pemecahan masalah. Harus disadari bahwa masingmasing sumber belajar memiliki kelebihan dan kelemahan.

b. Ekonomis, sumber belajar yang dipilih harus murah. Kemurahan di sini harus diperhitungkan dengan jumlah pemakai, lama pemakaian, langka tidaknya peristiwa itu terjadi dan akurat tidaknya pesan yang disampaikan.

c. Praktis dan sederhana, sumber belajar yang sederhana, tidak memerlukan peralatan khusus, tidak mahal harganya, dan tidak membutuhan tenaga terampil yang khusus.

d. Gampang didapat, sumber belajar yang baik adalah yang ada di sekitar kita dan mudah untuk mendapatkannya.

e. Fleksibel atau luwes, sumber belajar yang baik adalah sumber belajar yang dapat dimanfaatkan dalam berbagai kondisi dan situasi.

\subsubsection{Pengertian Situs}

Situs memiliki berbagai pengertian yang berbeda karena selain dalam dunia computer dan internet, didalam dunia sejarah juga terdapat istilah situs. Bila dalam dunia computer dan internet situs merupakan website, sebuah alamat yang bisa kita kunjungi dan berisi informasi tertentu tentang pemilik website, maka kata situs dalam dunia sejarah berhubungan dengan tempat atau area atau wilayah.

Menurut William Haviland (dalam Warsito 2012 : 25) mengatakan bahwa "tempat-tempat dimana ditemukan peninggalan-peninggalan arkeologi di kediaman makhluk manusia pada zaman dahulu dikenal dengan nama situs. Situs biasanya ditentukan berdasarkan survey suatu daerah".

Lebih lanjut William Haviland (dalam Warsito 2012 : 25) juga mengatakan bahwa " artefak/artefac adalah sisa-sisa alat bekas suatu kebudayaan zaman prehistori yang digali dari dalam lapisan bumi. Artefak ialah objek yang dibentuk atau diubah oleh manusia". 
Berdasarkan penjelasan diatas, dapat disimpulkan bahwa Situs diketahui karena adanya artefak. Ahli arkeologi mempelajari peninggalan-peninggalan yang berupa benda untuk menggambarkan dan menerangkan perilaku manusia. Jadi situs sejarah adalah tempat dimana terdapat informasi tentang peninggalan-peninggalan bersejarah. Salah satu contoh situs sejarah adalah Situs Cagar Budaya Candi Agung.

\subsubsection{Situs Sejarah Benteng Tundakan}

Benteng bersejarah ini berada di kawasan terpencil, tepatnya di Desa Tundakan, Kecamatan Awayan, Kabupaten Balangan.Benteng Tundakan merupakan salah satu kawasan yang digunakan pejuang sekitar tahun 1858 hingga 1861. Selain itu, bentuk Benteng Tundakan tidak sebagaimana yang dibayangkan orang, yang mana Benteng Tundakan adalah nama yang diberikan masyarakat di sekitar benteng tersebut.

Konon, Benteng Tundakan merupakan salah satu kawasan yang digunakan para pejuang kemerdekaan. Bahkan benteng Tundakan pernah dijadikan kawasan pertahanan oleh tokoh pejuang Kalsel Pangeran Antasari Pangeran Antasari bersama pejuang kemerdekaan lainnya seperti Tumenggung Jalil pernah menempati benteng tersebut.

Pada waktu itu, Pangeran Antasari merupakan tokoh pejuang kemerdekaan yang dicari-cari tentara Belanda dan untuk menghindari upaya penangkapan yang dilakukan tentara Belanda, Pangeran Antasari bersembunyi di kawasan Benteng Tundakan.Keberadaan Benteng Tundakan sempat diketahui tentara Belanda. Hingga akhirnya benteng tersebut diserang ratusan tentara Belanda sekitar. Dalam penyerangan tersebut Temanggung Jalil gugur, jasadnya dimakamkan tidak jauh dari kawasan Benteng Tundakan. 


\section{BAB III}

\section{METODE PENELITIAN}

\subsection{Jenis Penelitian}

Jenis penelitian yang digunakan dalam penelitian ini adalah deskriptif dengan pendekatan kuantitatif, dimana penelitian ini bermaksud untuk membuat deskripsi, gambaran, atau lukisan secara sistematis, factual dan akurat mengenai fakta-fakta, sifat-sifat serta hubungan antar fenomena yang diselidiki. Tujuan penelitian ini adalah 
peneliti ingin menjelaskan, memaparkan secara objektif mengenai "Pengaruh Situs Benteng Tundakan Sebagai Sumber Pembelajaran Sejarah Siswa Kelas XI SMAN 1 Paringin."

\subsection{Lokasi penelitian}

Penelitian dilakukan Kelas XI SMA Negeri 1 Paringin.

\subsection{Populasi dan Sampel}

Populasi dalam penelitian ini adalah seluruh siswa Kelas XI SMAN 1 Paringin. Sedangkan yang menjadi sampel dalam penelitian ini adalah terdiri dari 30 siswa Kelas XI SMAN 1 Paringin.

\subsection{Variable}

Yang menjadi variable dalam penelitian ini adalah :

a. Variable independen ( Variabel bebas ). Yang menjadi variable bebasdalam penelitian ini adalah Situs Candi Agung Sebagai Sumber Belajar (X).

b. Variable dependen ( Variable terikat ). Sedangkan yang menjadivariable terikat dalam penelitian ini adalah Hasil akademik mahasiswa (Y).

\subsection{Teknik pengumpulan data}

Adapun teknik pengumpulan data yang digunakan dalam penelitian ini, ialah sebagai berikut :

\section{Observasi}

Pouline (Indrawati dkk., 2007) mengemukakan bahwa observasi adalah suatu studi yang dilakukan secara terencana dan sistematis melalui pengamatan terhadap gejala-gejala spontan yang terjadi. observasi pada penelitian ini dilakukan untuk mengamati keikutsertaan mahasiswa dalam berorganisasi.

2. Kuesioner 
Kuesioner dalam penelitian ini menggunakan model skala Likert yang terdiri atas beberapa item dengan empat alternatif jawaban, yaitu SL (selalu), SR (sering), JR (jarang), TP (tidak pernah) dengan beberapa pernyataan tentang seputar organisasi dan akademik.

\subsection{Teknik Analisis Data}

a. Analisis Regresi Linear Sederhana

Untuk mengetahui bagaimana besarnya pengaruh keaktifan berorganisasi terhadap prestasi akademik mahasiswa, maka peneliti menggunakan analisis regresi linear sedehana yang dapat dirumuskan sebagai berikut :

$\mathrm{Y}^{\prime}=\mathrm{a}+\mathrm{bX}$

Keterangan:

$\mathrm{Y}^{\prime}=$ Variabel dependen (nilai yang diprediksikan)

$\mathrm{X}=$ Variabel independen

$\mathrm{a}=$ Konstanta (nilai $\mathrm{Y}$ ' apabila $\mathrm{X}=0$ )

$\mathrm{b}=$ Koefisien regresi (nilai peningkatan ataupun penurunan)

14

b. Uji t (Uji Parsial)

Uji ini digunakan untuk mengetahui apakah variabel independen (X) berpengaruh secara signifikan terhadap variabel dependen (Y). Signifikan berarti pengaruh yang terjadi dapat berlaku untuk populasi (dapat digeneralisasikan). Dimana $\mathrm{t}$ hitung $>\mathrm{t}$ tabel, $\mathrm{H} 1$ diterima dan $\mathrm{H} 0$ ditolak begitupun jika $\mathrm{t}$ hitung $<\mathrm{t}$ tabel, maka H0 diterima dan H1 ditolak. 


\section{Daftar Pustaka}

Anis, M. 2014. Sejarah, Pendidikan Sejarah, Dan Pendidikan Karakter Dialog Yang Tidak Pernah Dituntaskan. Banjarmasin: FKIP_Unlam Press

Putro, Herry 2014. Museum Sebagai Wahana Pendidikan Karakter Di Kalimantan Selatan . Banjarmasin: FKIP_Unlam Press

Susanto Heri 2016. Pendidikan dan kesadaran Nasionalisme. 307 